\title{
Photographic documentation during safe laparoscopic cholecystectomy
}

\section{Documentación fotográfica durante la colecistectomía laparoscópica segura}

\author{
Martín A. Bolívar-Rodríguez*, Adrián Pamanes-Lozano, Jaime Matus-Rojas, Marcel A. Cázarez-Aguilar \\ and Rodolfo Fierro-López \\ Department of General Surgery, Center of Research and Teaching in Health Sciences, Universidad Autónoma de Sinaloa, Hospital Civil de Culiacán, \\ Culiacán, Sin. Mexico
}

\begin{abstract}
Introduction: Laparoscopic cholecystectomy is the most frequent procedure for the general surgeon. Biliary injury is a concern that must be addressed with the purpose of lowering the rate. The critical view of safety (CVS) is a target of dissection that impulses safety during the procedure. Objective: Determine by an ambispective analysis the safety during dissection of laparoscopic cholecystectomy in Hospital Civil de Culiacán (México). Methods: Descriptive, ambispective, observational, cross-sectional. Patients admitted to the operating room for a laparoscopic cholecystectomy were scored with Doublet photography rating criteria from January 1st 2015 to January 31, 2017. Results: 321 patients were evaluated, $77.9 \%$ were female and $22.1 \%$ male. The mean age was $45.57 \pm 16.17$ years. $65.4 \%$ had admission diagnosis of cholelithiasis, $24.3 \%$ acute cholecystitis, $5.9 \%$ chronic cholecystitis, $3.7 \%$ hydrocolecist and $0.6 \%$ pyocolecist. Surgeries were scored with Doublet photography. The CVS was obtained in $41.4 \%$ of the procedures with a statistical significance between a HPB surgeon and a general surgery resident $(p \leq 0.05)$. Conclusion: Recording Doublet photography provides a reliable CVS dissection criterion. It can be easily reproduced during laparoscopic cholecystectomy. The identification of cystic structures adds to the culture of safety during laparoscopic cholecystectomy.
\end{abstract}

KEY WORDS: Laparoscopic cholecystectomy. Patient safety. Photography. Documentation.

\section{Resumen}

Introducción: La colecistectomía laparoscópica es la cirugía realizada con más frecuencia. La tasa de lesión en la vía biliar impulsa para implementar métodos de seguridad, como la visión crítica de seguridad (VCS). Objetivo: Determinar la documentación fotográfica ambispectiva durante la colecistectomía laparoscópica segura en el Hospital Civil de Culiacán. Método: Estudio descriptivo, observacional, ambispectivo, transversal, de pacientes sometidos a colecistectomía laparoscópica en el Hospital Civil de Culiacán, evaluados con criterios fotográficos de Doublet para asegurar si la VCS se obtuvo de manera satisfactoria, del 1 de enero de 2015 al 31 de enero de 2017. Resultados: Se analizaron 321 pacientes (77.9\% del sexo femenino y $22.1 \%$ del sexo masculino), con una edad promedio de $45.57 \pm 16.17$ años, y diagnóstico de colelitiasis (65.4\%), colecistitis aguda (24.3\%), colecistitis crónica (5.9\%), hidrocolecisto (3.7\%) o piocolecisto (0.6\%). Los cirujanos realizaron la calificación de las fotografías otorgando puntajes en la vista anterior, posterior y Doublet. Se determinó un 41.4\% de VCS satisfactoria mediante análisis Doublet, con diferencia estadísticamente significativa entre las calificaciones del cirujano hepatobiliar y el médico residente ( $p$ < 0.05). Conclusiones: La realización de las fotografías en pacientes con registros confiables de la VCS es ideal para la colecistectomía laparoscópica, permitiendo identificar adecuadamente las estructuras císticas y evitar la lesión de vía biliar.

PALABRAS CLAVE: Colecistectomía laparoscópica. Seguridad del paciente. Fotografía. Documentación.

\author{
Correspondence: \\ *Martín Adrián Bolívar-Rodríguez \\ Eustaquio Buelna, 91 \\ Col. Gabriel Leyva \\ C.P. 80030, Culiacán, Sin., México \\ E-mail: bolivarmartin64@ hotmail.com
}

Date of reception: 01-02-2018

Date of acceptance: 09-04-2018

DOI:10.24875/CIRUE.M18000022
Cir Cir. 2018;86:134-138

Contents available at PubMed www.cirugiaycirujanos.com 


\section{Introduction}

Laparoscopic cholecystectomy is the method of choice for the resolution of stone-related gallbladder diseases. Biliary tract injury has always been the most feared and devastating complication during cholecystectomy. In laparoscopic cholecystectomy, as compared with open cholecystectomy, biliary tract injury increased with a $0.6 \%$ injury rate, in comparison with the accepted indices that ranged from 0.1 to $0.25 \%$ during open cholecystectomy, with the rate increasing six times more in frequency ${ }^{1}$. Currently, the described percentage of bile duct injury during laparoscopic cholecystectomy varies between 0.1 and $1 \%$, with an average of $0.5 \%^{2}$. In 1995 , Steven M. Strasberg developed and explained the critical vision of safety (CVS) for laparoscopic cholecystectomy as a method to reduce the incidence of bile duct injury. It identifies that the most common cause of injury is failure to identify the structures involved in the dissection. The common bile duct is mistaken for the cystic duct and, less frequently, the cystic duct is taken for an aberrant duct ${ }^{3}$. However, despite not having evidence of a relationship with biliary tract injury and even when there are studies of thousands of patients with $0 \%$ documented bile duct injury, surgeons do not apply CVS during surgery ${ }^{4,5}$. To implement universal measures, the Society of American Gastrointestinal and Endoscopic Surgeons (SAGES) promotes strategies to universalize safe laparoscopic cholecystectomy ${ }^{6,7}$. The first point during the procedure is to dissect the CVS. To ensure that sufficient dissection is being achieved, Sanford and Strasberg ${ }^{8}$ developed a rating method using photo-documentation. The purpose of this study was to determine whether laparoscopic cholecystectomy at Hospital Civil de Culiacán is being carrying out with sufficient CVS dissection, as assessed with Sanford and Strasberg's criteria.

\section{Method}

A descriptive, ambispective, cross-sectional, observational study was designed, which included 321 laparoscopic cholecystectomy surgeries performed at Hospital Civil de Culiacán in the period comprised between January 1, 2015 and January 31, 2017. Videos of all surgeries that entered the operating room with a laparoscopic cholecystectomy surgical plan and that completed the procedure as planned were ambispectively analyzed. Surgeries that used any imaging tool, conversion to open surgery, bile duct exploration or subtotal cholecystectomy were excluded. Incomplete videos were disregarded. Surgeries were analyzed and two photographs were taken during the point of largest dissection and CVS exposure on anterior and posterior view, to then be assessed by a hepatobiliary surgeon and a general surgery resident. The collected information was used and entered to an Excel database and to the SPSS statistical program, version 23. Frequencies (absolute and relative) and means were calculated as central tendency measures, and ranges and standard deviations were calculated as measures of dispersion. Estimates of the $95 \%$ confidence intervals were carried out for each central estimator. For the comparison of proportions, the chi-square test was used, whereas for related samples, Student's t-test was employed.

\section{Results}

A study sample of 321 patients was identified, with an average age of 45.57 years and a standard deviation of 16.17 years (minimum 18 years and maximum 93 years); the male gender accounted for $22.1 \%$ (71), and the female gender for $77.9 \%$ (250). Patients admitted to the operating room were assigned a surgical plan for laparoscopic cholecystectomy, which was indicated for diseases such as cholelithiasis $(65.4 \%$; 210 patients), acute cholecystitis (24.3\%; 78 patients), pyocholecyst ( $0.6 \%$; 2 patients), chronic cholecystitis (5.9\%; 19 patients) and hydrocholecyst (3.7\%; 12 patients) (Table 1).

According to the criteria to rate the CVS photographs, pictures of the cystic structures were taken in order to expose their tubular composition, with or without small portions of adjacent tissue (Figs. 1 and 2), from the anterior and posterior view, which were analyzed by surgeons and residents. Among the former, $20.9 \%$ (67) rated the anterior view with 6 points, $19 \%$ (61) with 5 points, $15.3 \%$ (49) with 4 points, 13.4\% (43) with 3, $11.5 \%$ (37), 2 points, and $10.3 \%$ (33), only with 1 point. Lower scores were assigned in the rating of the photographs by resident doctors: the anterior view was assigned 6 points by $21.5 \%$ (69), 5 points were assigned by $34 \%$ (109), 4 points by $10 \%$ (32), 3 points were assigned by $11.5 \%$ (37), 2 points by $14.3 \%$ (46) and only 1 point by $5.6 \%$ (18) (Table 2).

In the photographic rating of the structures in the posterior view, the surgeons scored $4.4 \%$ (14) with 6 points, 3.4\% (11) with 5 points, 3.1\% (10) with 4 points, $1.6 \%$ (5) with 3 points, $3.7 \%$ (12) with 2 points, $6.2 \%$ 
Table 1. Pathology variables

\begin{tabular}{lcc}
\hline Variables & \multicolumn{2}{c}{ Laparoscopic cholecystectomy } \\
\cline { 2 - 3 } & $\mathbf{n}$ & $\%$ \\
\hline Cholelithiasis & 210 & 65.4 \\
Acute cholecystitis & 78 & 24.3 \\
Pyocholecyst & 2 & 0.6 \\
Chronic cholecystitis & 19 & 5.9 \\
Hydrocholecyst & 12 & 3.7 \\
Total & 321 & 100.0 \\
\hline
\end{tabular}

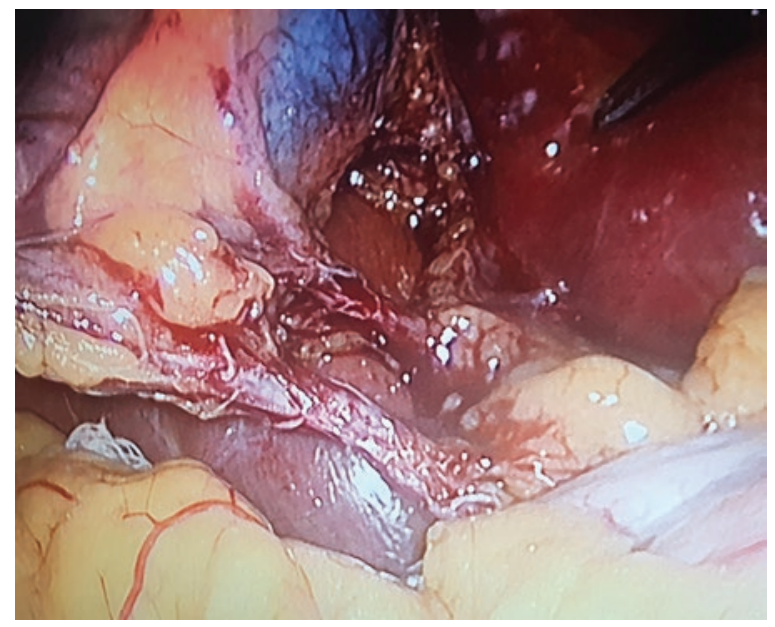

Figure 1. Critical view of safety, anterior view.

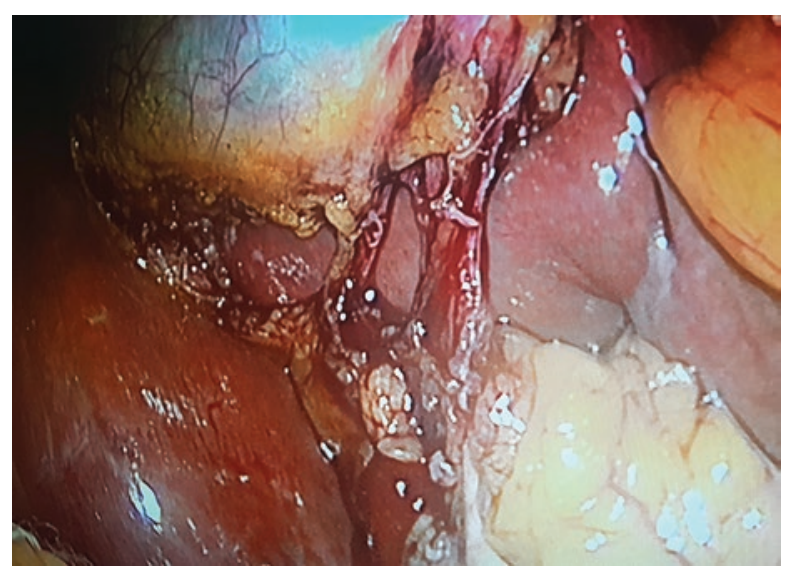

Figure 2. Critical view of safety, posterior view.

(20) only with1 point, and $77.6 \%$ (249) with 0 points. According to residents' perspectives, the scores were higher: in 3.1\% (10) the score was 6 points, in 5\% (16) it was 5 points, in $5 \%$ (16), 4 points, in $5.9 \%$ (19), 3 points, in $5.9 \%$ (19), 2 points, $12.5 \%$ (40) had only 1 point and $65.6 \%$ (201) had 0 points (Table 2).

Scores higher than 5 points are regarded as surgeries with sufficient dissection. In the anterior view, the hepatobiliary surgeon added up to $39.9 \%$ and the resident $55.5 \%$, for an average of $47.7 \%$. In the posterior view, the hepatobiliary surgeon added up to $7.8 \%$ and the resident $8.1 \%$, for an average of $7.95 \%$.

When the anterior and posterior view criteria are combined, the highest values for each criterion are added in order to obtain the doublet score. This allows differentiating structures that are difficult to appreciate due to the anatomical position the evaluated structures may have. Considering the criteria in a dynamic way allows clarifying and increasing the confidence to know that the CVS is being satisfactorily obtained.

The doublet criteria for the hepatobiliary surgeon reached sufficiency for $42 \%$ (136) of the sample; the resident rated $56 \%$ as sufficient (181). The average was $41.4 \%$ (133) of the patient sample (Fig. 3).

Statistically significant differences were obtained when the analysis by anterior and posterior view made by the surgeon and the resident physician was compared $(p=0.001)$.

\section{Discussion}

In this research, laparoscopic cholecystectomy was identified to be the most frequent procedure, and it is mainly the adult population that is affected, with an average of 45.57 years of age, and the female sex being more affected $(77.9 \%)$, which is a similar result to that reported in the research by Bonifaz Calvo and Palacio Vélez $z^{9}$. A surgical plan for laparoscopic was arranged for patients who were admitted to the operating room, mainly in those diagnosed with of cholelithiasis, acute cholecystitis, pyocholecyst, chronic cholecystitis and hydrocholecyst, as reported in the international literature.

The investigation conducted by Álvarez, et al. ${ }^{10}$ reported that the Strasberg technique should be applied, where pictures are taken when using the CVS in gaIlbladder surgery, in order to identify all the structures located in the hepatic hilum and being able to make the dissection with caution, with a 360-degree view, in order for the duct or cystic artery not to be overlooked. This is why this research was carried out, in order to have an adequate and effective procedure in the study subjects, since the main difficulty in this surgery has been reported to be a highly restricted visualization of adjacent structures.

Rating the CVS with the guidelines proposed by Sanford and Strasberg allows standardizing the laparoscopic cholecystectomy procedure in order to completely avoid bile duct injury secondary to the lack of 
Table 2. Anterior and posterior view scores

\begin{tabular}{|c|c|c|c|c|c|c|c|c|}
\hline \multirow[t]{2}{*}{ Points* } & \multicolumn{2}{|c|}{$\begin{array}{c}\text { Surgeon } \\
\text { anterior } \\
\text { view }\end{array}$} & \multicolumn{2}{|c|}{$\begin{array}{l}\text { Resident } \\
\text { anterior } \\
\text { view }\end{array}$} & \multicolumn{2}{|c|}{$\begin{array}{l}\text { Surgeon } \\
\text { posterior } \\
\text { view }\end{array}$} & \multicolumn{2}{|c|}{$\begin{array}{c}\text { Resident } \\
\text { posterior } \\
\text { view }\end{array}$} \\
\hline & $\mathrm{n}$ & $\%$ & $\mathrm{n}$ & $\%$ & $\mathrm{n}$ & $\%$ & $\mathrm{n}$ & $\%$ \\
\hline 0 & 31 & 9.7 & 10 & 3.1 & 249 & 77.6 & 201 & 62.6 \\
\hline 1 & 33 & 10.3 & 18 & 5.6 & 20 & 6.2 & 40 & 12.5 \\
\hline 2 & 37 & 11.5 & 46 & 14.3 & 12 & 3.7 & 19 & 5.9 \\
\hline 3 & 43 & 13.4 & 37 & 11.5 & 5 & 1.6 & 19 & 5.9 \\
\hline 4 & 49 & 15.3 & 32 & 10.0 & 10 & 3.1 & 16 & 5.0 \\
\hline 5 & 61 & 19.0 & 109 & 34.0 & 11 & 3.4 & 16 & 5.0 \\
\hline 6 & 67 & 20.9 & 69 & 21.5 & 14 & 4.4 & 10 & 3.1 \\
\hline
\end{tabular}

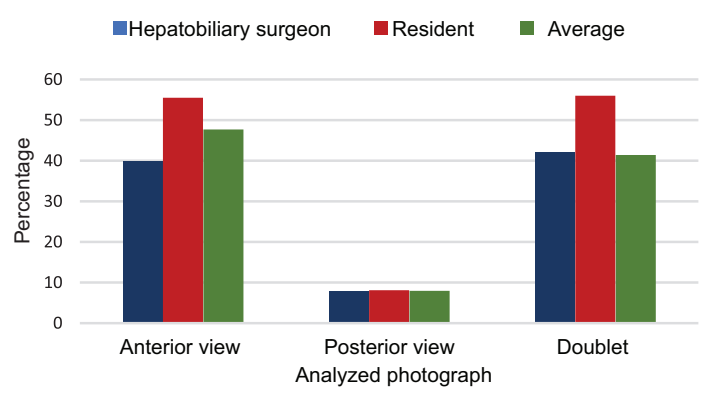

Figure 3. Percentage of photographs with sufficient score.

identification of structures during targeted dissection, and to permanently document with photographs the complete dissection ${ }^{8}$, as well as being able to use other surgical resources in case of not obtaining it and in this way offer a safe surgery, free of lesion of the bile duct.

Buddingh, et al..$^{11}$, in a retrospective photo-documentation analysis, identified that the range at which CVS can be satisfactorily distinguished is $34-70 \%$. Granting a score by means of doublet photo-documentation standardizes the criteria with objective bases and provides a better analysis with clear dissection goals.

Sanford and Strasberg ${ }^{8}$, in their study focusing on guiding the surgeons in doublet implementation and photo-documentation, referred insufficient scores in up to $25 \%$ of cases when the anterior and posterior views were individually analyzed, and up to $96 \%$ of success when analyzed by doublet photo-documentation. In this study, $41.4 \%$ of surgeries were shown to meet sufficient criteria by means of doublet photo-documentation. When the anterior and posterior views are individually compared, a significant difference between the images that could be identified on each window is observed. Anterior view sufficient dissection reached an average of $47.7 \%$ when the hepatobiliary surgeon and resident scores were combined. In contrast, the anterior view only reached an average of $7.95 \%$ between both assessors.

Doublet photo-documentation should provide the dynamic advantages that laparoscopic surgery allows. It is rated by means of two photographs, since it is the permanent, accessible and low-cost method available for easy reproduction. For each criterion, the highest score between the two perspectives should be considered in order to sufficiently distinguish the targeted dissection. If a sufficient score is achieved (5 points or more), then it means that the structures are already well distinguished from any of the perspectives, and that the CVS is well identified.

In the case of this investigation, we observed that in most of the analyzed surgeries, the surgeon does not focus his dissection towards the posterior window. The images obtained prior to the ligature, incision or clipping of the dissected tubular structures lack sufficient information to add adequate dissection criteria.

Comparing the studies by Emous et al. $^{12}$ and Plaisier et al. ${ }^{13}$, great CVS variability is demonstrated with regard to sufficient dissection, despite always having the surgical strategy for achieving it. However, these authors did not use any objective or numerical scoring method to assess their dissection.

Our results, which show an average of $41.4 \%$ for satisfactory surgeries rated with Sanford and Strasberg's doublet criteria, reflect similar results to those already published by these authors. However, this work demonstrates sufficient dissection with a numerical and objective score.

With the results, we observed that the CVS dissection criteria are met in less than half the performed surgeries, even when the surgery ends up being a laparoscopic cholecystectomy. Alternative surgical resources, such as imaging tests, conversion to open surgery, biliary tract exploration or subtotal cholecystectomies, were not included in the study. Therefore, the analyzed surgeries that did not meet sufficient CVS criteria were $58.6 \%$ (188). These surgeries have a risk of bile duct injury of 0.4 and $0.2-1 \%$ according to the most current consensus based on USA and European statistics, respectively. So far, not a single CVS dissection-related bile duct injury has been published and, according to the studies by Avgerinos et al., ${ }^{14}$ Heistermann et al. $^{15}$, Misra et al. ${ }^{16}$, Sanjay et al., ${ }^{17}$ and Yegiyants and Collins ${ }^{7}$, the bile duct injury $0 \%$ ratio is supported. No double-blind study has been 
published where CVS can be shown to really reduce the incidence of bile duct injury to $0 \%$; Strasberg believes that probably it will never be conducted, since it would require at least 4500 procedures per group to be able to achieve a $p$-value of 0.05 . However, the expert consensus recommends CVS as the first step in the dissection objectives for all laparoscopic cholecystectomy procedures, taking it as part of a culture towards safe surgery ${ }^{6}$.

To optimize the results and see the change in the surgical paradigm towards safe laparoscopic cholecystectomy, all surgeons practicing within Hospital Civil de Culiacán should be instructed on the dissection goals, and be in agreement with the expert in that they are being satisfactorily achieved. Doublet photo-documentation should be promoted in all laparoscopic cholecystectomy surgeries and be maintained as a permanent registry in patients' medical records. Part of the dissemination of universal safety criteria lies in the identification of the mechanism of injury. In laparoscopic cholecystectomies of difficult dissection or where CVS cannot be satisfactorily identified, the surgical alternative methods proposed by SAGES should be used.

\section{Conclusions}

The most feared complication during the procedure of choice for the resolution of gallbladder pathology, laparoscopic cholecystectomy, is bile duct injury. The main mechanism of injury related to the procedure is secondary to a poor identification of the structures manipulated in the dissection by surgeons with little experience. Mortality and morbidity associated with bile duct injury during laparoscopic cholecystectomy can occur up to 15 years after surgery.

Photographic verification of the surgical procedure is ideal to permanently record the correct dissection and identification of target structures for surgery. This decreases the incidence of bile duct injury to $0 \%$.
Strategies that allow surgeons to perform satisfactory dissections and document them with intraoperative photographs should be implemented.

\section{Conflicts of interest}

The authors declare not having any conflicts of interest.

\section{References}

1. Deziel DJ, Millikan KW, Economou SG, Doolas A, Ko ST, Airan MC. Complications of laparoscopic cholecystectomy: a national survey of 4,292 hospitals and an analysis of 77,604 cases. Am J Surg. 1993;165:9-14.

2. Downing SR, Datoo G, Oyetunji TA, Fullum T, Chang DC, Ahuja N. Asian race/ethnicity as a risk factor for bile duct injury during cholecystectomy. Arch Surg. 2010;145:785-7.

3. Strasberg SM, Brunt LM. Rationale and use of the critical view of safety in laparoscopic cholecystectomy. J Am Coll Surg. 2010;211:132-8.

4. Claros N, Laguna R, Pinilla R. Estrategias intraoperatorias para evitar la lesión de vía biliar durante la realización de una colecistectomía laparoscópica. Rev Med La Paz. 2011;17:5-15.

5. Strasberg SM, Brunt LM. The critical view of safety: why it is not the only method of ductal identification within the standard of care in laparoscopic cholecystectomy. Ann Surg. 2017;265:464-5.

6. Society of American Gastointestinal and Endoscopic Surgeons. Brunt LM. The SAGES Safe Cholecystectomy Program. 2017 Manages by BSC Management, Inc. Disponible en: https://www.sages.org/safe-cholecystectomy-program.

7. Yegiyants S, Collins JC. Operative strategy can reduce the incidence of major bile duct injury in laparoscopic cholecystectomy. Am Surg. 2008;4:985-7.

8. Sanford DE, Strasberg SM. A simple effective method for generation of a permanent record of the critical view of safety during laparoscopic cholecystectomy by intraoperative "doublet" photography. J Am Coll Surg. 2014;218:170-8.

9. Bonifaz Calvo JE, Palacio Vélez AF. Experiencia en reconstrucción de la vía biliar, secundaria a lesiones mayores iatrogénicas. Cir Gen. 2015;37:70-81.

10. Álvarez LF, Rivera D, Esmeral ME, García MC, Toro DF, Rojas OL. Colecistectomía laparoscópica difícil, estrategias de manejo. Rev Colomb Cir. 2013;28:186-95.

11. Buddingh KT, Nieuwenhuijs VB, van Buuren L, Hulscher JBF, de Jong JS, van Dam GM. Intraoperative assessment of biliary anatomy for prevention of bile duct injury: a review of current and futrure patient safety interventions. Surg Endosc. 2011;25:2449-61.

12. Emous M, Westerterp M, Wind J, Eerenberg JP, van Geloven AA. Registering the critical view of safety: photo or video? Surg Endosc. 2010;24:2527-30.

13. Plasier PW, Pauwels MM, Lange JF. Quality control in laparoscopic cholecystectomy: operation notes, video or photo print? HPB. 2001;3:197-9.

14. Avgerinos C, Kelgiorgi D, Touloumis Z, Baltatzi L, Dervenis C. One thousand laparoscopic cholecystectomies in a single surgical unit using the "critical view of safety" technique. J Gastrointest Surg. 2009;13:498-503.

15. Heistermann HP, Tobusch A, Palmes D. [Prevention of bile duct injuries after laparoscopic cholecystectomy. "The critical view of safety"]. Zentralbl Chir. 2006;131:460-5.

16. Misra M, Schiff J, Rendon G, Rothschild J, Schwaitzberg S. Laparoscopic cholecystectomy after the learning curve: what should we expect? Surg Endosc. 2005;19:1266-71.

17. Sanjay P, Fulke JL, Exon DJ. 'Critical view of safety' as an alternative to routine intraoperative cholangiography during laparoscopic cholecystectomy for acute biliary pathology. J Gastrointest Surg. 2010;14:1280. 